\title{
Allele frequencies distribution of 16 forensic STR loci in a Western Sicilian population sample
}

\author{
Elvira Ventura Spagnolo ${ }^{1 *}$, Cristina Mondello², Salvatore Procaccianti ${ }^{1}$, Simona Marretta ${ }^{2}$, Stefania Zerbo ${ }^{1}$, \\ Alessio Asmundo ${ }^{2}$ and Antonella Argo ${ }^{1}$
}

\begin{abstract}
The PowerPlex ${ }^{\oplus}$ ESI 17 Fast and ESX 17 Fast Systems represent faster cycling versions released by Promega ${ }^{\oplus}$ to follow the requirements of ENFSI and EDNAP groups' for new STR genotyping systems in Europe. Allele frequencies and forensic parameters were estimated in a population sample of 120 unrelated healthy individuals living in Sicily (Western Sicilian population sample) using PowerPlex ${ }^{\circledR}$ ESI 17 Fast and PowerPlex ${ }^{\circledR} 17$ Fast Systems. Full concordance of the results for both systems was observed. No significant deviation from Hardy-Weinberg equilibrium was detected. The observed heterozygosity changed from 0.85833 for FGA to 0.95 for TH01. The combined power of discrimination for the 16 loci was $>0.999999$.
\end{abstract}

Keywords: Allele frequencies, Str, Italian population, DNA database, PowerPlex

\section{Introduction}

The International Scientific Community establishes the crucial role of the population studies on allele frequencies and the importance to extend DNA database for forensic purposes. This study analyzed the allele frequencies and genetic parameters of 16 STR loci in a Western Sicilian population sample.

Western Sicily has been the object of many denominations. 120 unrelated Sicilian individuals have been selected for at least 3 generations. This study belongs to the only Western Sicilian population.

Sicily is the biggest and one of the most populated regions in Italy. The Sicilian population amounts approximately to $5,077,487$ people (2015), in which only 162,000 are foreigners.

The population study is performed by PowerPlex ESI 17 Fast and ESX 17 Fast Systems designed with the new loci recommended by the European Network of Forensic Science Institutes (ENFSI) and European DNA Profiling Group (EDNAP) (McLaren et al. 2014; Tucker et al. 2011, 2012; Gill et al. 2006).

\footnotetext{
* Correspondence: elvira.ventura@unipa.it

${ }^{1}$ Legal Medicine Section - Department for Health Promotion and Mother-Child

Care, University of Palermo, Via del Vespro 129, 90127 Palermo, Italy

Full list of author information is available at the end of the article
}

\section{Materials and methods DNA extraction}

Blood samples and buccal swabs were collected from 120 unrelated occidental Sicilian individuals. DNA was extracted using Prepfiler Forensic DNA Extraction kit (Applied Biosystems - Life Technologies) and a Nanodrop1000 spectrophotometer (Thermo Scientific, Waltham, MA) was employed to measure the DNA concentration.

Blood samples and buccal swabs were collected anonymously from 120 unrelated healthy individuals living in Western Sicily acquiring their informed consents.

DNA extraction was performed using the Prepfiler Forensic DNA Extraction kit (Applied Biosystems - Life Technologies) according to the manufacturer's instructions.

\section{Amplification}

Approximately $1 \mathrm{ng} / \mu \mathrm{l}$ of template DNA was amplified using PowerPlex ESI and ESX 17 fast System (Promega). The PCR amplification was performed using the GeneAmp PCR System 9700 thermocycler (Applied Biosystems) on the basis of the suggested manufacturer guidelines of the STR kit tested in this study. PCR products were analyzed by capillary electrophoresis and positive and negative controls were carried out as specified in the PowerPlex ESI and ESX $17^{\circ}$ fast System (Promega) user's manual. 


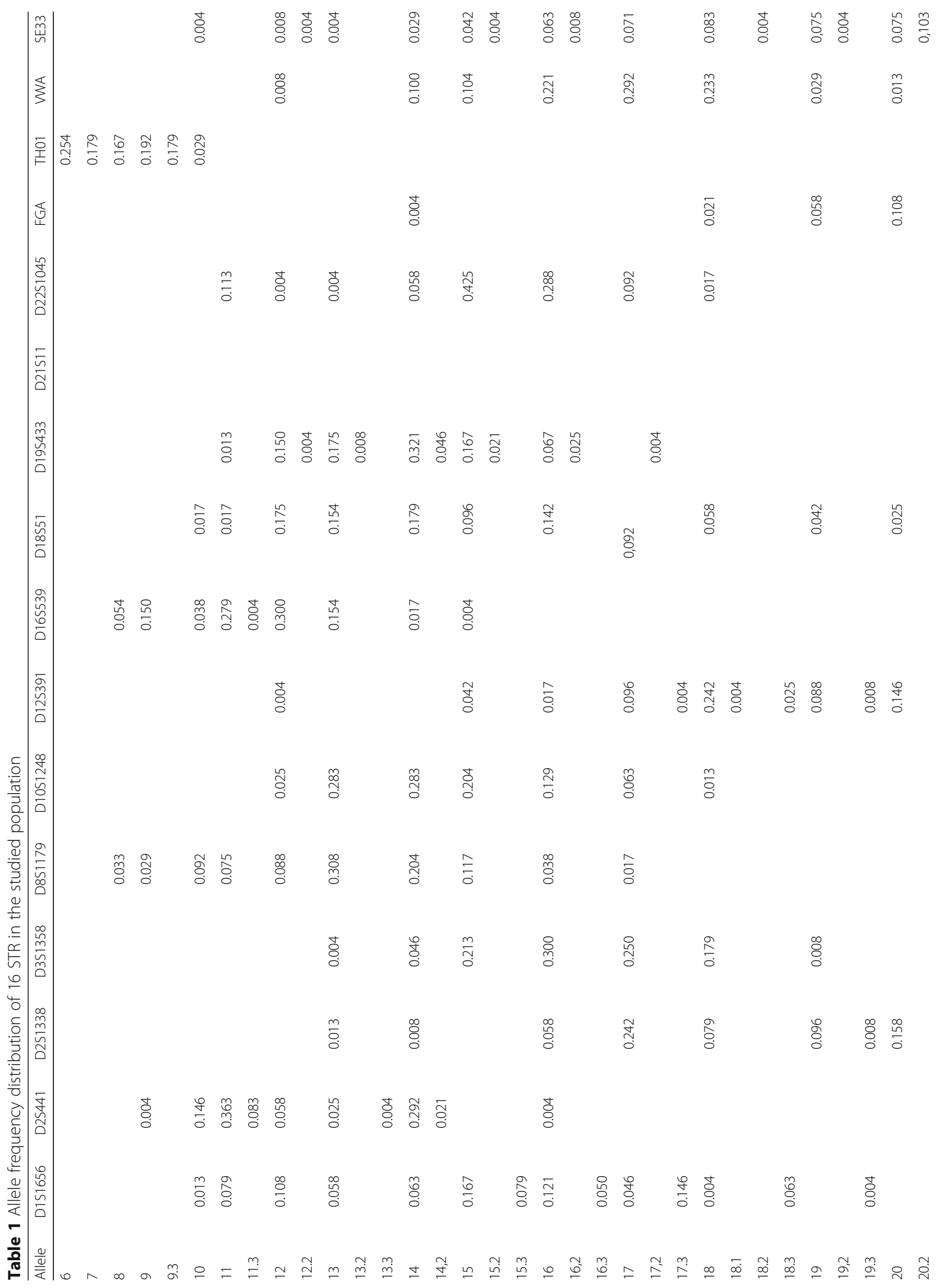




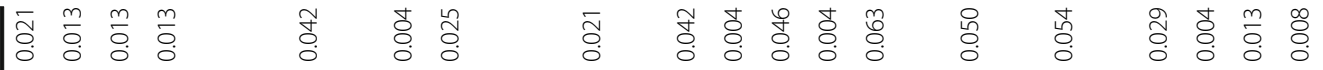

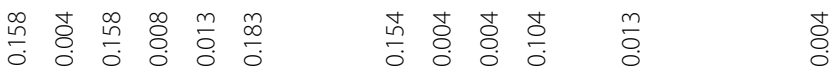

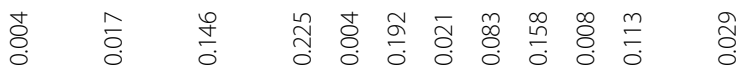

¿্ঠ

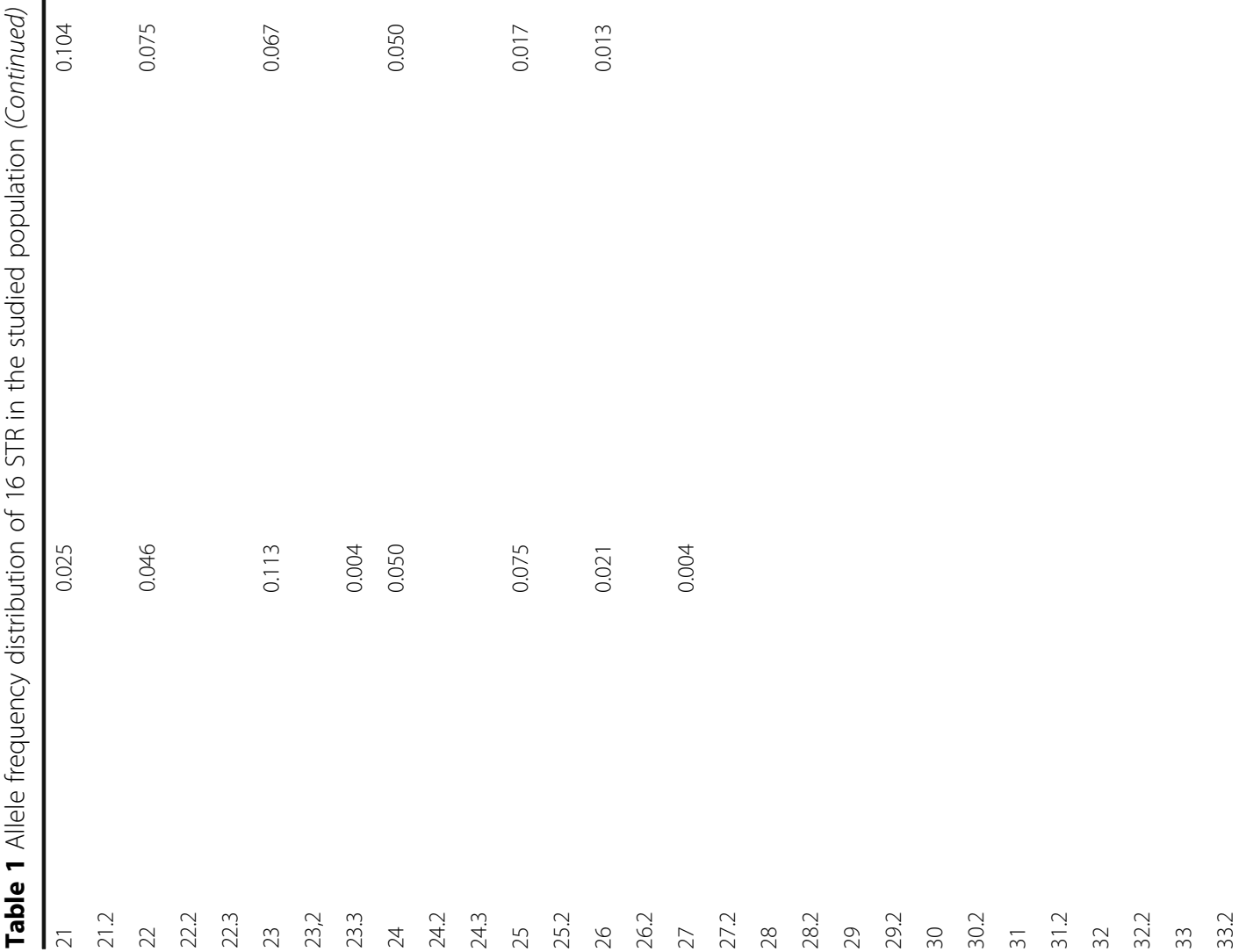




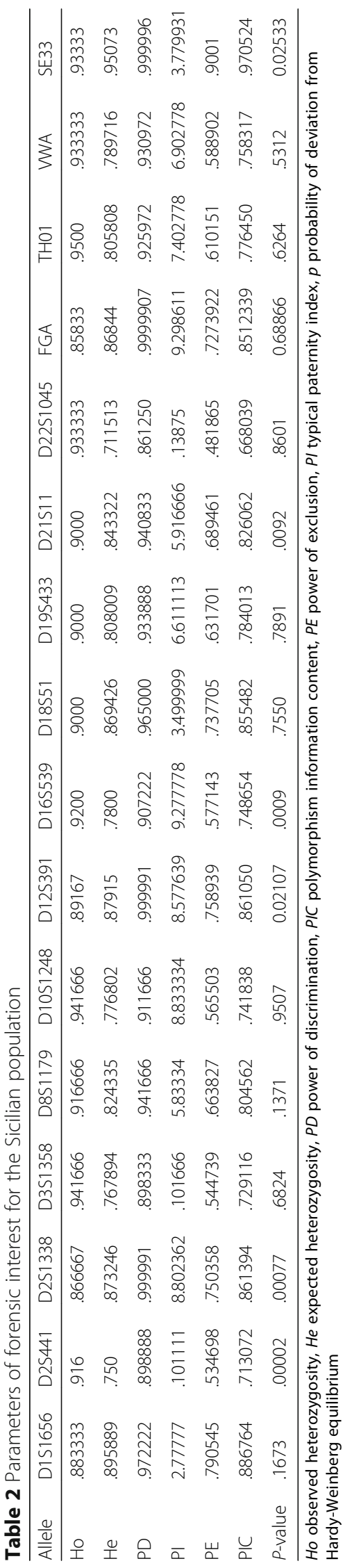




\section{DNA electrophoresis and analysis}

All the amplification products were detected by capillary electrophoresis and genotyping was carried out on the ABI PRISM 310 Genetic Analyzer (Applied Biosystems). Data obtained were analyzed using GeneMapper ID v3.2.1 Software (Applied Biosystems).

\section{Population study}

Allelic frequencies for all loci and additional relevant forensic parameters such as expected heterozygosity $(\mathrm{He})$ and observed heterozygosity (Ho), polymorphic information content (PIC), power of discrimination (PD) and power of exclusion (PE) were calculated by GenePop (v.4.5.1) software (Rousset 2008). The Hardy-Weinberg equilibrium was tested by the $p$-value obtained by setting 100 batches with 5000 interactions per batch in the Markov chain method (Guo and Thompson 1992). Allele frequencies of 16 STR and parameters of forensic interest are summarized in Tables 1 and 2.

\section{Results and discussion}

All loci exhibited an observed heterozygosity $(\mathrm{Ho})$ greater than 0.85833 (FGA), with the highest value at 0.95 for TH01 and values of polymorphism information content (PIC) ranging between 0.668039 for D22S1045 and 0.970524 for SE33.

The lower power discrimination (PD) was observed for D22S1045 (0.861250) and the highest for D2S1338, D12S391 and SE33 (0.99999) The power of exclusion (PE) ranged from 0.481865 for D22S1045 to 0.9001 for SE33.

The study confirmed that all the markers were useful for forensic purposes: the combined power of discrimination was $>0.999999$. No significant deviation from Hardy-Weinberg expectations was found. Full concordance at all autosomal loci and amelogenin for both systems was observed.

Allele frequencies for studied 16 STR loci were compared to Italian population data (Berti et al. 2011). The data from Sicilian population was not significantly different from the Italian ones, except for the highest power of discrimination that was observed also for D2S1338 and D12S391.

In conclusion, we report the allele frequencies and forensic statical parameters in a Southern Italian population (Western Sicily). The results contribute to extending knowledge on DNA population data in Italy for forensic purposes. Our data on PowerPlex ESX 17 Fast System and PowerPlex ESI 17 Fast System demonstrate that both systems represent very remarkable tools for forensic human identification and kinship relationship.

Funding

No funding for the study.

\section{Authors' contributions}

Study concept and design: EVS, CM, SP. Acquisition of data: SP, SZ, AAsmundo, AArgo. Analysis and interpretation of data: SM, CM, EVS Drafting of the manuscript: EVS, CM. Study supervision: EVS, CM.

All authors read and approved the final manuscript.

Competing interests

The authors declare that they have no competing interests.

\section{Publisher's Note}

Springer Nature remains neutral with regard to jurisdictional claims in published maps and institutional affiliations.

\section{Author details}

${ }^{1}$ Legal Medicine Section - Department for Health Promotion and Mother-Child Care, University of Palermo, Via del Vespro 129, 90127 Palermo, Italy.

${ }^{2}$ Department of Biomedical and Dental Sciences and Morphofunctional Imaging, University of Messina, via Consolare Valeria, 1, 98125 Messina, Italy.

Received: 13 April 2017 Accepted: 12 July 2017

Published online: 07 August 2017

\section{References}

Berti A, Brisighelli F, Bosetti A, Pilli E, Trapani C, Tullio V, Franchi C, Lago G, Capelli C (2011) Allele frequencies of the new European standard set (ESS) loci in the Italian population. Forensic Sci Int Genet 5(5):548-549

Gill P, Fereday L, Morling N. Schneider PM. The evolution of DNA databasesrecommendations for new European STR loci. Forensic Sci Int 2006; 156(2-3):242-244

Guo SW, Thompson EA (1992) Performing the exact test of hardy-Weinberg proportion for multiple alleles. Biometrics 48(2):361-372

McLaren RS, Bourdeau-Heller J, Patel J, Thompson JM, Pagram J, Loake T, Beesley D, Pirttimaa M, Hill CR, Duewer DL, Kline MC, Butler JM, Storts DR (2014) Developmental validation of the PowerPlex ${ }^{\oplus}$ ESI 16/17 fast and PowerPlex ${ }^{\oplus}$ ESX 16/17 fast systems. Forensic Sci Int Genet. 13:195-205

Rousset F (2008) Genepop'007: a complete re-implementation of the genepop software for windows and Linux. Mol Ecol Resour 8(1):103-106

Tucker VC, Hopwood AJ, Sprecher CJ, McLaren RS, Rabbach DR, Ensenberger MG, Thompson JM, Storts DR (2011) Developmental validation of the PowerPlex ${ }^{\circledast}$ ESI 16 and PowerPlex ${ }^{\oplus}$ ESI 17 systems: STR multiplexes for the new European standard. Forensic Sci Int Genet. 5(5):436-448

Tucker VC, Hopwood AJ, Sprecher CJ, McLaren RS, Rabbach DR, Ensenberger MG, Thompson JM, Storts DR (2012) Developmental validation of the PowerPlex ${ }^{\circledast}$ ESX 16 and PowerPlex ${ }^{\oplus}$ ESX 17 system. Forensic Sci Int Genet 6(1):124-131

\section{Submit your manuscript to a SpringerOpen ${ }^{\circ}$ journal and benefit from:}

- Convenient online submission

- Rigorous peer review

- Open access: articles freely available online

- High visibility within the field

- Retaining the copyright to your article

Submit your next manuscript at $>$ springeropen.com 